\title{
The Study on Strength Properties of Light Weight Concrete using Light Weight Aggregate
}

\author{
B. Devi Pravallika ${ }^{1}$, K. Venkateswara Rao ${ }^{2}$ \\ ${ }^{1}$ PG Scholar (Structural Engineering), Gudlavalleru Engineering College, Gudlavalleru, AP, India \\ ${ }^{2}$ Associate Professer (Civil Engineering), Gudlavalleru Engineering College, Gudlavalleru, AP, India
}

\begin{abstract}
Concrete is widely noted to be most expensive constituents in the entire construction industry. Many research works has been carried out on concrete mixes which had encouraged the development of material with partial replacement of natural aggregate like pumice stone, thermocol beads, saw dust. For the construction of structures, the new sources that is produced from environmental waste is Natural aggregate which reduces the self weight and helps in constructing of larger precast units. light weight concrete plays a prominent role in reducing the density of concrete structures where reduction of self weight is an important factor which may increases thermal insulation by relating of structural response \& serviceability. Light weight aggregate is of natural origin mostly volcanic tuff which acts as active pozzolonas when used as aggregates. In this study the strength and durability properties of M40 concrete by partial replacement of coarse aggregate with natural light weight aggregate pumice stone will be studied. The properties of conventional M40 concrete are compared with properties of concrete with light weight aggregate, produced by replacing coarse aggregate with pumice stone by $0 \%, 10 \%, 20 \%, 30 \%, 40 \%$ and $50 \%$. The physical and mechanical properties of natural aggregate are evaluated. An optimum control mix is designed based on structural light weight concrete M40 using the light weight aggregate pumice stone as a partial replacement to coarse aggregate. For this purpose 6 sets were prepared in which each set comprises of 15 cubes, 3 cylinders and 3 beams. Slump test were carried out for each mix in the fresh state. The compressive strength of cubes (150mmX150mmX150mm), split tensile strength for cylinders (150mm diaX300mm height), flexural strength for (beams 500X100X100mm) tests will be carried out to determine the strength of concrete at 7and 28 days which were performed in the hardened state.
\end{abstract}

Keywords: Natural light weight aggregate, coarse aggregate, cement, super plasticizer (gleninum sky 8630), fine aggregate

\section{Introduction}

The word "concrete" itself represents a very large segment to the total load of the structure which is playing a vital role in the present versatile construction industry. it is having high probable strength gaining capacity from many years because of its sustainable hardening capacity which helps in making the structure very strong. One of the ways to reduce the weight of a structure is the use of lightweight aggregate concrete (LWAC). In recent years, more awareness has been paid to the development of lightweight aggregate concrete. In this study, the replacement of usual aggregate by light weight aggregate concrete and the method of using pozzolanic material is studied. Light weight aggregate is of natural origin mostly volcanic tuff which acts as active pozzolonas when used as aggregates. Natural light weight aggragate as a pozzolonic material in light weight concrete has grown as much that it became an essential ingredient in concrete, particularly for making high strength \& high performance concrete. An active pozzolona is a alumino siliceous material in finely divided form which chemically reacts with calcium hydroxide by forming calcium silicate hydrate and other cementitious compounds. For the reduction of cost in the construction purpose mineral admixture are widely used in concrete for reducing the amount of cement required. Moreover pozzolans will act as byproduct materials in saving energy consumption and weight reduction. The effect of pozzolonic material in light weight aggregate concrete improves workability, increases water tightness, lower heat of hydration and reduce alkaliaggregate reaction. At present more awareness has been made to the development of light weight aggregate concrete which is the most probable way in reducing the weight of structure and acts as a relatively new material where weight saving is an important factor. Light weight concrete is a type of concrete material that is lighter than the conventional concrete because of varying material composition. It maintains good durability in satisfying the required demands by making the concrete as a high performance material. When an light weight aggregate is made for the same crushing strength the density of concerte obtained will be $35 \%$ lower when compared to the normal weight concrete Light weight concrete is having an oven dried density of not less than $800 \mathrm{~kg} / \mathrm{m}^{3}$ and not even more than $2000 \mathrm{~kg} / \mathrm{m}^{3}$ when compared to normal weight concrete.

The major benefit in adopting the light weight concrete mixes is of reducing the self weight of the structure up to $15 \%$ or more. When there is less unit weight of aggregate then comparatively the unit weight of concrete will also be low and it is done by replacing the normal weight aggregate to the light weight materials. The materials which will occur naturally are pumice stone, volcanic tuff, porous limestone, foamed lava. Among these aggregates pumice stone which is of natural light weight aggregate is being choosen as a best material for the partial replacement to coarse aggregate. it gives good strength when compared to the other materials More research work is being carried out because of its low density, porous in nature and high volume occupancy.It includes an enlarging agent which increases the volume of the mixture. It is having low-density by preserving large voids and when placed on the wall it forms cement films.

The method of the study will be conducted on by replacing the usual aggregate by natural light weight aggregate. The advantageous way by using light weight concrte in the sesmic design of structures is having lower modulus of elasticity, low coefficient of thermal expansion and thermal conductivity. By using light weight concrete, the design

Volume 5 Issue 6, June 2016 www.ijsr.net 


\section{International Journal of Science and Research (IJSR) \\ ISSN (Online): 2319-7064 \\ Index Copernicus Value (2013): 6.14 | Impact Factor (2015): 6.391}

flexibility will be high, reduction in substantial cost savings, dead load is reduced, cyclic loading is improved, good structural response, longer spans is achieved, fire ratings will be better, having feasible thinner sections, structural members will be of small size, reinforcing steel will be less and foundations costs will be lower. Adequate ductility is achieved by the addition of reduced dead weight to the structure where erection loss and transport costs will be less for prefabricated members. It includes an enlarging agent that increases the volume of the mixture by acquiring lowdensity and thermal conductivity.

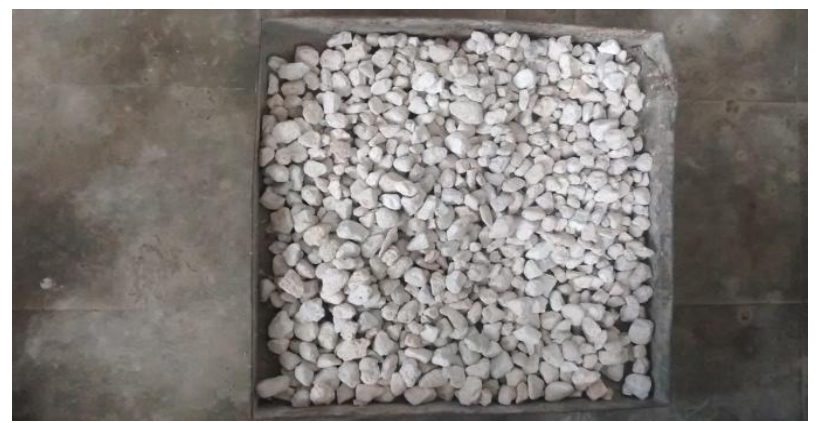

Figure 1: Pumice stone

\subsection{Properties of Pumice Stones:}

Pumice stone is a textural material formed from rapidly cooling viscous molten rock by trapping gas bubbles which results in a foamy whipped glass. The word pumice is derived from latin word pumeu, that meaning foam. It is even formed in deep undergrounds and when the magma erupts from a vent by forming the gases which leaves a forthy structure. The transformed magma is the amorphous rock or pumice. Pumice is found in various textures such as pyroclastic flows, accumulated drifts, piles and at the river banks by the action of wind.the pure pumice is obtained in a floating mass or near the shore as it saturates by sinking and near the water bodies by the action of wind. Pumice is an amorphous plentiful rock that is found all over the country where not all pumice is ideal for refining and use in industry. In ancient days many innovative techniques are adopted in concrete mixtures with pumice by greeks and romans. The majority of the ancient structures were built with the pumice stone.it is not a localized product by its varying characteristics.the market demand of pumice is high because of its mohs scale hardness, purity level, whitness and the ability of the company that mines and refines

\section{Chemical Composition of Pumice Stone}

The pumice stone is extremely light weight rock which float on the surface of water for longer time physical properties are governed by the celluar structure of matrix. These cells are independent of each other at which level of sound and heat of Hydration are low The chemical properties of pumice stone varies from place to place which primarly comprises of silicon dioxide, aluminum oxide and trace amounts of other oxides. The mohs scale hardness of pumice is $5.5-6$.it is chemically inert with pourness nature and having microscopic size which contains $75 \%$ silicon oxide and $85 \%$ of pumice grain volume
Table 1: Chemical Composition of pumice stone

\begin{tabular}{|c|c|}
\hline Oxide composition & Pumice stone \% \\
\hline $\mathrm{SIO}_{2}$ & 71.91 \\
\hline $\mathrm{AL}_{2} \mathrm{O} 3$ & 12.66 \\
\hline $\mathrm{Fe}_{2} \mathrm{O}_{3}$ & 1.13 \\
\hline $\mathrm{CaO}$ & 1.46 \\
\hline $\mathrm{Mgo}$ & 0.32 \\
\hline $\mathrm{Na}_{2} \mathrm{O}$ & 3.45 \\
\hline $\mathrm{K}_{2} \mathrm{O}$ & 4.30 \\
\hline Calcification lors & 4.53 \\
\hline Specific Gravity & 0.80 \\
\hline
\end{tabular}

$\mathrm{SIO}_{2}$ ratio forms a chemical structure which gives abrasive property to rocks. $\mathrm{AL}_{2} \mathrm{O} 3$ composition gives high strength to heat and fire. $\mathrm{Na}_{2} \mathrm{O} \& \mathrm{k}_{2} \mathrm{O}$ are the minerals that shows reaction property in tentive industry

\section{2 pumice stone applications:}

- Used in industries as a filler, abrasive, filtration and concrete applications. It is even used as an consumer products

- Pumice stone is mostly an ideal light weight aggregate which is used in the construction of concrete blocks

- It is used as an abrasive in milder applications on television glass, computer circuit boards and in exfoliating skin

- It is a friable material which indicates that when crushed in to a fine powder it does not loose its ability to abrade and polish by having sharp edges

- It acts as an good filler which is non - crystalline, non toxic and non - hazardous. It acts as a functional filler in paint industry which gives low density and stain resistance.

- It provides anti skid resistance for its coarses grade properties. Rubber and plastic industry even uses pumice as a filler material

- In non - soil hydroponic applications it acts as a growing medium for plants and in horticulture industry pumice is used to areate soil which helps to retain moisture capacity

- It helps in increasing the $\mathrm{R}$ value of concrete by a factor of 4, which is more advantageous to save energy in construction field

- It serves as a filtration media in large culinary systems and it works mainly in construction pumice pozzoloan is used to increase durability and strength to concrete

- It is used in roads, bridges, precast concrete cubes, for the purpose of decorative concrete and cementatious grouts

\section{Experimental Programme}

The experimental program was carried out on cubes, cylinders and beams. The details of the materials Used for these specimens and testing procedure incorporated in the test program are presented in the Subsequent sections.

\subsection{Tests on coarse Aggregate}

The coarse aggregate passing through $20 \mathrm{~mm}$ size sieve and retaining on $10 \mathrm{~mm}$ sieve as shown in given below table. 


\section{International Journal of Science and Research (IJSR) \\ ISSN (Online): 2319-7064}

Index Copernicus Value (2013): 6.14 | Impact Factor (2015): 6.391

Table 2: Properties of coarse aggregate

\begin{tabular}{|l|c|c|}
\hline S. No. & Property & Value \\
\hline 1 & Crushing value & $14.36 \%$ \\
\hline 2 & Impact value & $2.7 \%$ \\
\hline 3 & Abrasion value & $11 \%$ \\
\hline 4 & Specific gravity & 2.7 \\
\hline 5 & Water absorption & $0.5 \%$ \\
\hline
\end{tabular}

\subsection{Tests on fine aggregate}

The fine aggregate passing through $4.75 \mathrm{~mm}$ sieve is tested as per IS: 2386(part III) and the properties are Listed below.

Table 3: Properties of fine aggregate

\begin{tabular}{|c|c|c|}
\hline Sl. No. & Property & Value \\
\hline 1 & Sieve analysis & Zone II \\
\hline 2 & Specific gravity & 2.67 \\
\hline
\end{tabular}

\subsection{Tests on Cement}

The following tests on cement were carried out Consistency test, setting times test, Fineness test, and Soundness test

Table 4: properties of cement

\begin{tabular}{|c|c|c|}
\multicolumn{2}{c}{ Table 4: properties of cement } \\
\hline S1. No. & Property & Value \\
\hline 1 & Fineness test & $7.4 \%$ \\
\hline 2 & $\begin{array}{c}\text { Setting time } \\
\text { a)initial } \\
\text { b)final }\end{array}$ & $\begin{array}{c}40 \mathrm{~min} \\
270 \mathrm{~min}\end{array}$ \\
\hline 3 & Specific gravity & 3.15 \\
\hline 4 & Soundness test & $4.5 \mathrm{~mm}$ \\
\hline
\end{tabular}

\section{Casting and Mix Proportion}

The casting is done by taking materials of Cement, coarse aggregate, fine aggregate and pumice stone in required volume.

- The cubes are casted in 12 , cylinders 12 , beams 12 for the testing of compressive strength in 7 and 28 days.

- The cubes are casted in 12 , cylinders 12 , beams 12 for the testing of split tensile strength in 7 and 28 days.

- The cubes are casted in 12 , cylinders 12 , beams 12 for the testing of flexural strength in 7 and 28 days.

Table 5: Mix proportion for M 40 grade concrete

\begin{tabular}{|c|c|c|c|}
\hline $\begin{array}{c}\text { Cement } \\
\left(\mathrm{Kg} / \mathrm{m}^{3}\right)\end{array}$ & $\begin{array}{c}\text { Fine Aggregate } \\
\left(\mathrm{Kg} / \mathrm{m}^{3}\right)\end{array}$ & $\begin{array}{c}\text { Coarse } \\
\text { Aggregate }\left(\mathrm{Kg} / \mathrm{m}^{3}\right)\end{array}$ & $\begin{array}{c}\text { Water content } \\
\text { In lit }\end{array}$ \\
\hline 447 & 588.9 & 1234 & 170 \\
\hline 1 & 1.31 & 2.76 & 0.39 \\
\hline
\end{tabular}

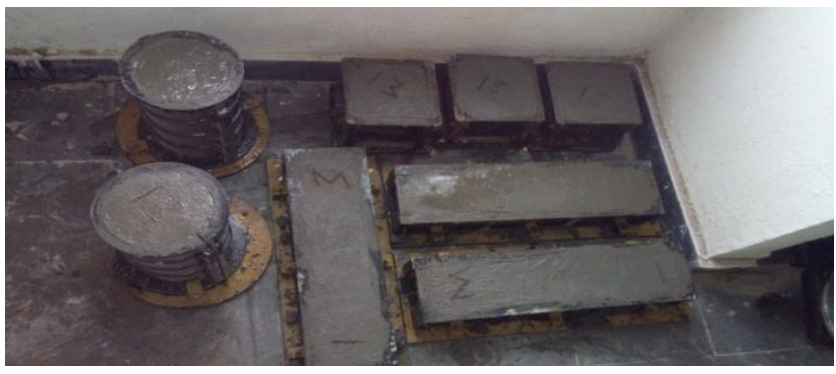

Figure 2: casting cubes, beams and cylinders

\section{Specimen Testing Results and Values}

\subsection{Compressive Test}

The compressive strength is obtained after curing of 7 and 28 days at 28 days the compressive strength is...........Mpa it will increases in a long period of time and exceeds the compressive strength values of nominal concrete.

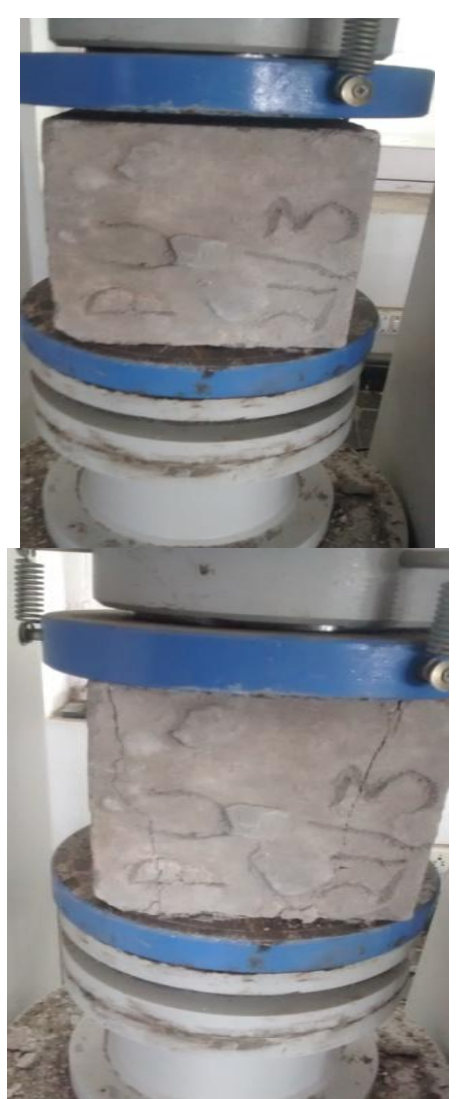

Figure 3: Compressive test on cubes

Table 6: compressive strength for 7 days 28 days

\begin{tabular}{|c|c|c|c|}
\hline $\begin{array}{c}\text { partially } \\
\text { replaced pumice } \\
\text { stone }\end{array}$ & \multicolumn{3}{|c|}{ Compressive strength } \\
\cline { 2 - 4 } & 7 days $\left(\mathrm{n} / \mathrm{mm}^{2}\right)$ & 28 days $\left(\mathrm{n} / \mathrm{mm}^{2}\right)$ & $\begin{array}{c}\text { Unit weight } \\
\mathrm{kg}\end{array}$ \\
\hline Conventional & 34.57 & 49.87 & 8.86 \\
\hline $10 \%$ & 32.17 & 49.32 & 8.16 \\
\hline $20 \%$ & 28.42 & 41.37 & 6.85 \\
\hline $30 \%$ & 22.39 & 33.72 & 6.45 \\
\hline $40 \%$ & 20.65 & 27.66 & 5.88 \\
\hline $50 \%$ & 18.16 & 25.84 & 5.68 \\
\hline
\end{tabular}

\subsection{Split tensile Test}

The compressive strength is obtained after curing of 7 and 28 days at 28 days the tensile strength is...........Mpa it will increases in a long period of time and exceeds the split tensile strength values of nominal concrete. 


\section{International Journal of Science and Research (IJSR) \\ ISSN (Online): 2319-7064}

Index Copernicus Value (2013): 6.14 | Impact Factor (2015): 6.391

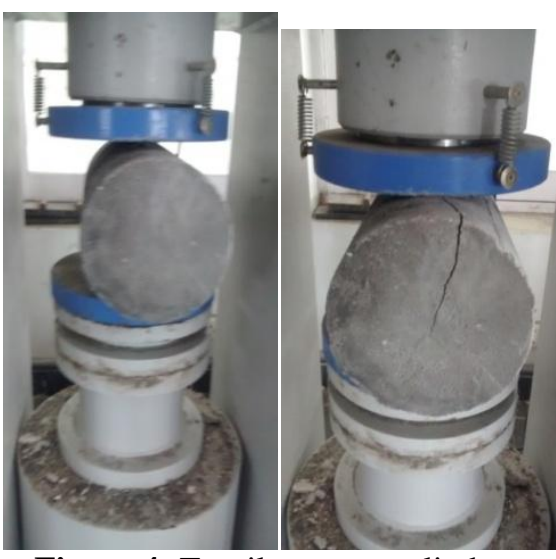

Figure 4: Tensile test on cylinders

Table 7: split tensile strength for 7 days 28 days

\begin{tabular}{|c|c|c|}
\hline partially replaced & \multicolumn{2}{|c|}{ Split tensile strength } \\
\cline { 2 - 3 } pumice stone & 7 days $\left(\mathrm{n} / \mathrm{mm}^{2}\right)$ & 28 days $\left(\mathrm{n} / \mathrm{mm}^{2}\right)$ \\
\hline Conventional & 3.53 & 4.2 \\
\hline $10 \%$ & 3.23 & 4.00 \\
\hline $20 \%$ & 3.03 & 3.66 \\
\hline $30 \%$ & 2.69 & 3.31 \\
\hline $40 \%$ & 2.42 & 2.94 \\
\hline $50 \%$ & 2.29 & 2.81 \\
\hline
\end{tabular}

\subsection{Flexural test}

The compressive strength is obtained after curing of 7 and 28 days at 28 days the flexural strength is............Mpa it will increases in a long period of time and exceeds the flexural strength values of nominal concrete.
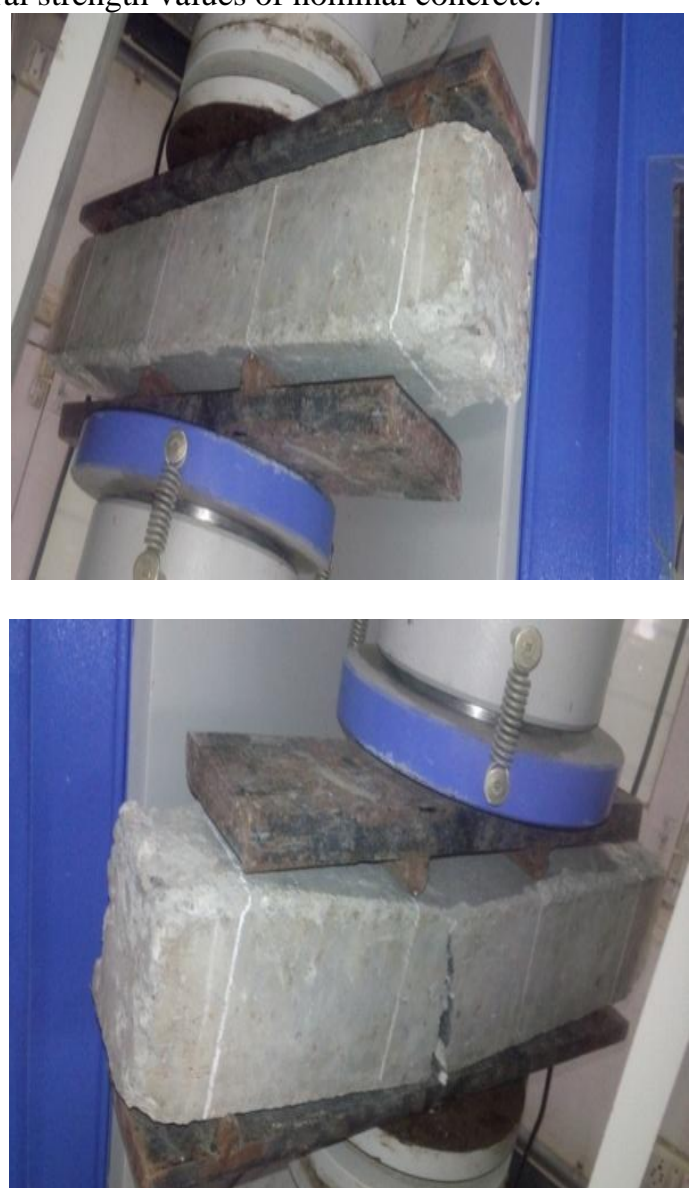

Figure 5: Flexural test on beams
Table 8: flexural strength for 7 days 28 days

\begin{tabular}{|c|c|c|}
\hline partially replaced & \multicolumn{2}{|c|}{ flexural strength } \\
\cline { 2 - 3 } pumice stone & 7 days $\left(\mathrm{n} / \mathrm{mm}^{2}\right)$ & 28 days $\left(\mathrm{n} / \mathrm{mm}^{2}\right)$ \\
\hline Conventional & 4.11 & 4.94 \\
\hline $10 \%$ & 3.97 & 4.91 \\
\hline $20 \%$ & 3.73 & 4.0 \\
\hline $30 \%$ & 3.31 & 4.06 \\
\hline $40 \%$ & 2.97 & 3.61 \\
\hline $50 \%$ & 2.82 & 3.44 \\
\hline
\end{tabular}

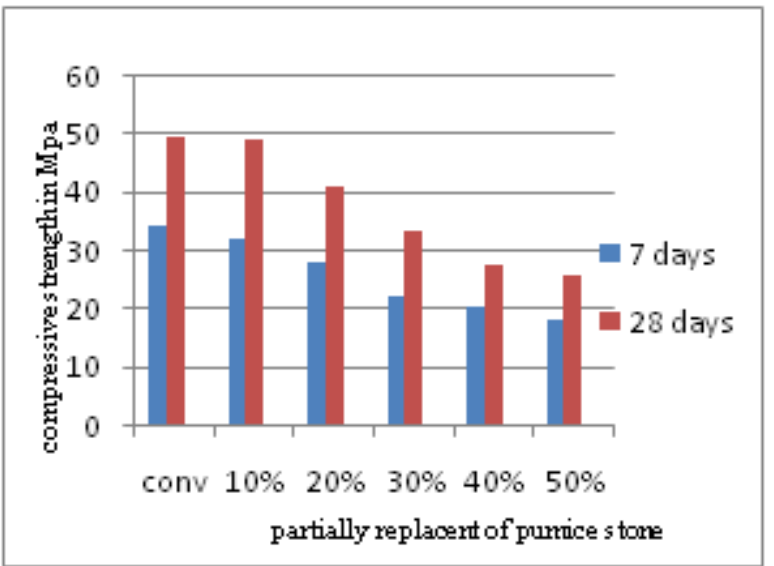

Graph 1: compressive strength for pumice stone in 7 days $\& 28$ days

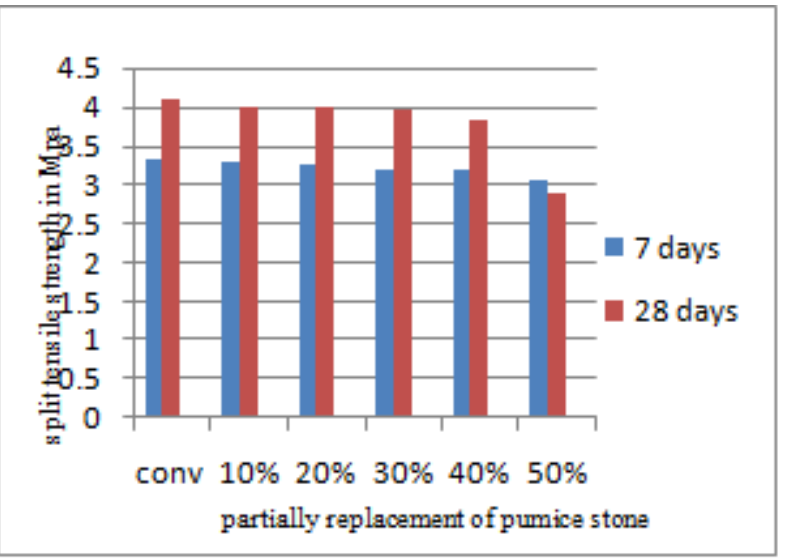

Graph 2: split tensile strength for pumice stone in 7 days \& 28 days

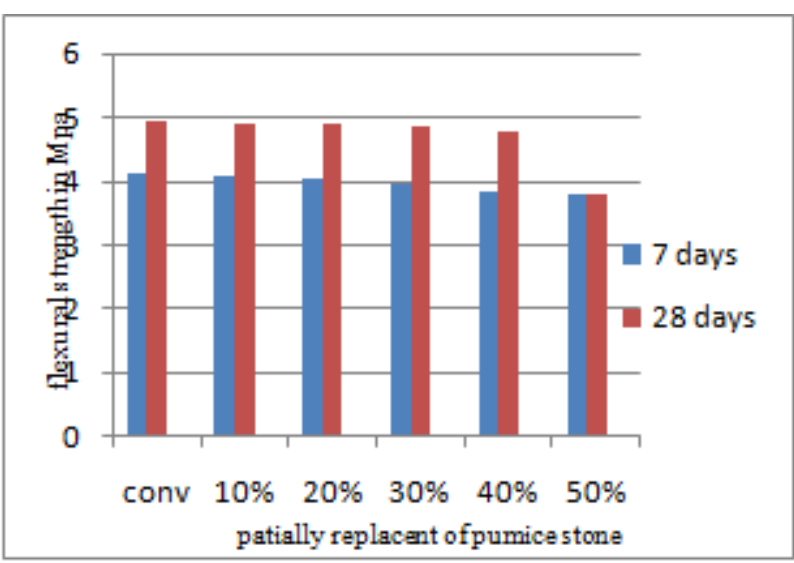

Graph 3: flexural strength for pumice stone in 7 days $\& 28$ days

\section{Volume 5 Issue 6, June 2016} www.ijsr.net 


\section{Conclusion}

Concrete specimens show good results in light weight for $50 \%$ partial replacement of natural aggregate with pumice stone.

- The increasing percentage of pumice stones will show negative impact on strength of concrete (strength decreases).

- Generally Pumice stone absorbs more water compared to the nominal coarse aggregate, to overcome this problem additional usage of super plasticizes is added.

- For replacement of $20 \%$ of pumice stone gives optimum value beyond $20 \%$ the compressive strength value decreases.

\section{References}

[1] Lakshmi kumar minapu, M K M V Ratnam, Dr. U Rangaraju December (2014) "Experimental study on light weight aggregatee concrete with pumice stone ,silica fume and fly ash as a partial replacement of coarse aggregate" vol 3, issue 12,

[2] N. Sivalinga Rao, Y.Radha Ratna Kumari, V. Bhaskar Desai, B.L.P. Swami (2013) "study on Fibre Reinforced Light Weight Aggregate (Natural Pumice Stone) Concrete."

[3] P. priyadharshini, g. mohan ganesh and a. s. santhi june (2012) "A Review on Artificial Aggregates" issn 09745904, volume 05, No. 03(01), pp. 540 - 546.

[4] Dr. v.bhaskar desai, sathyam June (2014) "Basic properties of artificial lightweight aggregate by Using industrial by product (fly ash)" volume 5, issue 6, pp.66 $-67$.

[5] serkan suba March (2009) "The effects of using fly ash on high strength lightweight concrete produced with expanded clay aggregate" volume 4, pp. $275-288$.

[6] Syed Mudabir Altaf, Mir Mohammad Shoaib Mauloodi, HOD Zubair Ahmad Bhat, Raja Minad Ajaz Mrch (2015) "Study of Effect of Light Weight Aggregate Containing Fly Ash on Properties of Concrete", volume 2, issue 3, pp. $197-202$.

[7] Mix design 10262:2009.

[8] Indian code IS 456:2007.

Volume 5 Issue 6, June 2016 www.ijsr.net 